\title{
ELITO SLIDININKŲ VARŽYBINĖS VEIKLOS CHARAKTERISTIKA
}

\author{
Algirdas Čepulẻnas \\ Lietuvos kūno kultūros akademija, Kaunas, Lietuva
}

\begin{abstract}
Algirdas Čepulėnas. Profesorius socialinių mokslų (edukologijos) habilituotas daktaras. Lietuvos kūno kultūros akademijos Sporto technologijų katedros vedejjas. Mokslinių tyrimų kryptis — sportininkų treniravimo sistemos, rengimo valdymo modeliavimas.
\end{abstract}

\section{SANTRAUKA}

Tinkamai individualiai suplanuotas dalyvavimas varžybose garantuoja nuoseklu sportininko fizinio darbingumo gerẻjima, puikius rezultatus per pagrindines varžybas.

Tyrimo tikslas - ištirti pasaulio elito slidininku varžybinę veikla per olimpini 2005-2006 m. sezonq ir nustatyti varžybinès veiklos apimti, struktūrinius komponentus ir specifiškuma iki startu olimpinèse žiemos žaidynèse. Tyrimo objektas - slidininku lenktynininku, Turino olimpiniu žiemos žaidyniu individualiose lenktynèse užèmusiu 1-10 vieta, varžybinès veiklos komponentai (startu skaičius, nuotoliai, sportiniai rezultatai).

Slidininkai, užèmę 1-10 vieta $30 \mathrm{~km}$ kombinuotose lenktynèse (Pursuit), iki starto olimpinèse žaidynèse po 8-12 kartu dalyvavo Pasaulio slidinejimo taurès ir FIS kategorijos slidinèjimo lenktynèse. Šeši slidininkai, 30 km lenktynèse užèmę vietas pirmame dešimtuke, pateko ir i pirma $50 \mathrm{~km}$ lenktyniu laisvuoju (čiuožimo) stiliumi pajègiausiuju dešimtuka. Šeši slidininkai, $15 \mathrm{~km}$ lenktynèse klasikiniu stiliumi užème 1 -10 vietq, iki olimpiniu žaidyniu dalyvavo po 7-13 kartu ivairiu slidinéjimo nuotoliu lenktynèse.

Slidininkai, individualiose slidinèjimo sprinto lenktynèse užème 1 -10 vieta, iki šio olimpinio starto dalyvavo nuo 5 iki 29 kartu individualiose sprinto lenktynèse. Šios grupès slidininkai (išskyrus Norvegijos slidininka T. A. Hetland) kitose olimpinès slidinejimo programos individualiose rungtyse nedalyvavo.

Elito slidininkus pagal ju varžybinès veiklos specifika galima skirstyti i dvi grupes: vidutiniu, ilguju nuotoliu slidininkai ir slidininkai sprinteriai. Pagal elito slidininku rengimosi pagrindiniams startams strategija ir varžybinès veiklos rezultatyvuma ǐssiskiria trys grupès slidininku: klasikinio stiliaus slidininkai, universalūs slidininkai, činožiamojo stiliaus slidininkai.

Raktažodžiai: žiemos olimpinès žaidynès, elito slidininku varžybinè veikla, klasikinis stilius, laisvasis stilius, slidinejjimo sprintas.

\section{IVADAS}

$\mathrm{M}$ okslininkai (Раменская, 2000; Fominas, 2001; Pfützner et al., 2002; Шустин, 2003; Kindinger et al., 2004), aptardami sportininkų (tarp jų ir slidininkų) rezultatus olimpinèse žiemos žaidynèse ir sportinio rengimo tendencijas, pažymi, kad labai svarbu analizuoti sportininkų varžybinę veiklą ir optimizuoti ju rengimą olimpinėms žaidynėms pagal individualius gebejjimus. Sporto varžybos yra ne tik sportininku parengtumo palyginimo, bet ir veiksmingo sportinio rengimo priemonè (Karoblis, 2005). Viena vertus, sportininko pasirodymas varžybo- se yra vienas iš sportininko rengimo tikslų, kita vertus - varžybas galima vertinti ir kaip treniravimo formą, modeliuojančią varžybų sąlygas (Мелленберг, Сайдхужин, 1994; Верхошанский, 1998; Suslovas, 1999).

Varžybų krūvis - tai fizinis krūvis, kuri pakelia sportininkas per varžybas, ir varžybų, kuriose dalyvauja sportininkas, skaičius (Karoblis, 2005). Planuojant sportininko rengimą varžybu laikotarpiu būtina tinkamai suderinti treniravimo vyksmą su dalyvavimu varžybose (Suslovas, 1999, 2002; Karoblis, 2005). Varžybos, atsižvel- 
giant $\mathfrak{i}$ atsakingu varžybu terminus, padeda igyti sportinę formą (Suslovas, 1999). Dalyvavimas varžybose per metini rengimo ciklą turi būti tinkamai suplanuotas ir nukreiptas pagrindiniam strateginiam tikslui - pasiekti geriausių rezultatu per pagrindines varžybas (Шустин, 2003). Olimpiniais metais varžybinès veiklos struktūra, optimalus startų skaičius turi būti planuojamas atsižvelgiant i sportininkų organizmo adaptacijos prie varžybinių krūvių galias ir atsigavimo trukmę po varžybinès veikos krūvių (Suslovas, 2002; Шустин, 2003). Sportininku varžybinès veiklos optimizavimas per olimpinių metu ciklą — svarbus sèkmingo rengimo veiksnys. Rengiantis olimpinėms žaidynėms, startai neturètu sportininkams sukelti didelès psichinès ittampos (Рубин, 1999; Pfützner et al., 2002; Шустин, 2003). Per pastaraji dvidešimtmetį olimpinių žaidynių ir pasaulio slidinejjimo čempionatų slidinèjimo lenktynių varžybų programos dažnai keitèsi, pasipildè naujomis rungtimis. Dabar slidinèjimo lenktynių varžybinę programą sudaro: slidinèjimo lenktynès klasikiniais, čiuožiamaisiais būdais, lenktynès atskiru ir bendruoju startu, individualios ir komandinès sprinto lenktynès, estafete, kombinuotos lenktynès „Pursuit“ (pusè nuotolio šliuožiama klasikiniais būdais, o antra - čiuožiamaisiais, lenktynių metu slidininkai keičia slides ir lazdas). Kiekviena slidinejimo rungtis kelia specifinių reikalavimų slidininko organizmo adaptacijai prie varžybinès veiklos (Раменская, 2000). Slidininkų rengimas varžyboms pasidare sudètingesnis. Slidininkams vis sunkiau pasiekti aukščiausio lygio sportinių rezultatų lenktynèse klasikiniu ir laisvuoju stiliumi. Pastebima tendencija: slidininkai daugiau specializuojasi klasikinio arba laisvojo stiliaus, trumpujų arba ilgujų nuotolių lenktynėms (Плохой, 1995; Čepulėnas, 1998; Раменская, 2000). Nuotoliu iveikimo taktika taip pat skirtinga, pradedant varžybas atskiru ir bendruoju startu. Tų pačiu slidininkų organizmo adaptacijos prie fizinio krūvio rodikliai šliuožiant skirtingais slydimo būdais irgi skiriasi (Stöggl et al., 2006; Watts et al., 2006).

Sportinès formos igijimo valdymas susijęs su tam tikru sportininkui tinkamiausių startų skaičiumi ir jų paskirstymu varžybu laikotarpio mezociklais (Верхошанский, 1998; Suslovas, 1999). Elito slidininkų ${ }^{1}$ varžybinès veiklos apimties ir struktūros analizè metiniu rengimo ciklu ir prieš

1 Elito slidininkai - slidininkai, užimantys $1-10$ vietą olimpinèse žaidynèse, pasaulio čempionate, Pasaulio taurès varžybose. svarbiausias sezono varžybas - olimpines žaidynes, pasaulio čempionatus yra aktuali problema, bet literatūroje mažai nagrinejjama.

Tyrimo tikslas - ištirti pasaulio elito slidininkų varžybinę veiklą per olimpini 2005-2006 m. sezoną ir nustatyti varžybinès veiklos apimti, struktūrinius komponentus bei specifiškumą iki startų olimpinèse žiemos žaidynèse.

Tyrimo objektas - slidininkų lenktynininku, Turino olimpinių žiemos žaidynių individualiose lenktynėse užèmusių $1-10$ vietas, varžybinès veiklos komponentai (startų skaičius, nuotoliai, sportiniai rezultatai).

Metodai ir organizavimas. Atliekant tyrima taikyta: literatūros šaltinių, dokumentų analizè, lyginamoji ir metaanalizė (Kardelis, 2002), matematinè statistika. Išanalizuoti 33-jų slidininkų, Turino olimpinių žiemos žaidynių individualiose lenktynèse užėmusių $1-10$ vietą, varžybinès veiklos rodikliai per olimpini sezoną iki startų olimpinėse žaidynèse. Analizuoti šių slidininkų rezultatai ir per Pasaulio slidinejjimo taurès varžybas (užimtos vietos Pasaulio taurès varžybų galutineje įskaitoje). Duomenys gauti iš oficialiu Tarptautinès slidinejjimo federacijos (FIS) dokumentų: biografinès medžiagos apie elito slidininkų dalyvavimą varžybose, Turino olimpinių žaidynių slidinėjimo lenktynių varžybų protokolų, Pasaulio slidinejimo taurès varžybu galutinès įskaitos dokumentu (Cross-country ${ }^{1,3,4}$ ).

\section{REZULTATAI}

2006 m. olimpinių žiemos žaidynių slidinèjimo lenktyniu programos pirma rungtis buvo $30 \mathrm{~km}$ kombinuotos lenktynès bendruoju startu. Slidininkai, šiose lenktynèse užèmę $1-10$ vietą (1 lent.), iki olimpinio starto po 8-12 kartų dalyvavo Pasaulio slidinejjimo taurès ir kitose FIS kategorijos slidinėjimo lenktynèse (Cross-country $y^{1}$. Tik aštuntą vietą užèmęs slidininkas B. M. nurodyto rango varžybose buvo startavęs keturis kartus. Slidininkai po 3-7 kartus dalyvavo $15 \mathrm{~km}$ lenktynèse, po $1-2$ kartus $30 \mathrm{~km}$ lenktynèse bendruoju startu ir 1-2 kartus - kombinuotose lenktynèse. Olimpiniu čempionu tapęs Rusijos slidininkas tris kartus buvo startavęs sprinto lenktynèse. Aštuoni pirmo dešimtuko slidininkai paskutini kartą oficialiose varžybose (Pasaulio taurès $15 \mathrm{~km}$ lenktynèse) dalyvavo likus septynioms dienoms iki olimpinio starto. Olimpinis čempionas D. E. ir devintą vietą užèmęs slidininkas O. M. po 


\begin{tabular}{|c|l|c|c|c|c|c|c|c|}
\hline \multirow{2}{*}{$\begin{array}{c}\text { Užimta } \\
\text { vieta }\end{array}$} & $\begin{array}{c}\text { Slidininko pavardè, } \\
\text { vardas }\end{array}$ & $\begin{array}{c}10 \\
\mathrm{~km}\end{array}$ & $\begin{array}{c}15 \\
\mathrm{~km}\end{array}$ & $\begin{array}{c}30 \\
\mathrm{~km}\end{array}$ & $\begin{array}{c}\text { Kombinuotos } \\
\text { lenktynès } 15 \mathrm{~km} \\
\text { „K“+15 km „C““ }\end{array}$ & Sprintas & Iš viso & $\begin{array}{c}\text { Dienų skaičius } \\
\text { nuo paskutinio } \\
\text { iki olimpinio šio } \\
\text { nuotolio starto }\end{array}$ \\
\hline 1 & Dementjev Eugenij & - & 6 & 1 & 2 & 3 & 12 & 21 \\
\hline 2 & Estil Frode & - & 7 & 2 & 2 & - & 11 & 6 \\
\hline 3 & $\begin{array}{l}\text { Piller Cottrer } \\
\text { Pietro }\end{array}$ & - & 5 & 2 & 2 & - & 9 & 6 \\
\hline 4 & Di Centa Giorgio & - & 6 & 2 & 2 & - & 10 & 6 \\
\hline 5 & Soedergren Anders & - & 6 & 2 & 1 & - & 9 & 6 \\
\hline 6 & Vittoz Vincent & - & 7 & 1 & 2 & - & 10 & 6 \\
\hline 7 & Botvinov Mikhail & 2 & 5 & 1 & - & - & 8 & 6 \\
\hline 8 & Bajcicak Martin & - & 3 & - & 1 & - & 4 & 21 \\
\hline 9 & $\begin{array}{l}\text { Odnodvordcev } \\
\text { Maksim }\end{array}$ & - & 6 & - & 1 & 2 & 9 & 6 \\
\hline 10 & Bauer Lukas & 1 & 6 & 1 & - & - & 8 & 6 \\
\hline
\end{tabular}

\begin{tabular}{|c|c|c|c|c|c|c|c|c|c|}
\hline \multirow[b]{2}{*}{$\begin{array}{l}\text { Užimta } \\
\text { vieta }\end{array}$} & \multirow[b]{2}{*}{$\begin{array}{c}\text { Slidininko pavardè, } \\
\text { vardas }\end{array}$} & \multicolumn{7}{|c|}{ Startų skaičius iki olimpinio starto } & \multirow{2}{*}{$\begin{array}{c}\text { Dienų } \\
\text { skaičius nuo } \\
\text { paskutinio } \\
\text { iki olimpinio } \\
\text { šio nuotolio } \\
\text { starto }\end{array}$} \\
\hline & & $\begin{array}{r}10 \\
\mathrm{~km}\end{array}$ & $\begin{array}{r}15 \\
\mathrm{~km}\end{array}$ & $\begin{array}{r}30 \\
\mathrm{~km}\end{array}$ & $\begin{array}{l}\text { Kombinuotos } \\
\text { lenktynės } 15 \mathrm{~km} \\
\text { „K“+ } 15 \mathrm{~km} \text { „Č“ }\end{array}$ & Maratonas & Sprintas & Iš viso & \\
\hline 1 & Veerpalu Andrus & 1 & 6 & - & 1 & 1 & 3 & 12 & 11 \\
\hline 2 & Bauer Lukas & 1 & 6 & 1 & 1 & - & - & 9 & 4 \\
\hline 3 & Angerer Tobias & - & 3 & 2 & 1 & - & 6 & 12 & 4 \\
\hline 4 & Rotchev Vassil & - & 2 & 1 & 1 & - & $8+$ SK & $12+\mathrm{SK}$ & 2 \\
\hline 5 & Mae Jaak & 1 & 6 & 1 & 1 & 1 & 1 & 11 & 11 \\
\hline 6 & Olsson Johan & - & 4 & 2 & 2 & - & - & 8 & 4 \\
\hline 7 & Schluetter Andreas & 1 & 6 & 2 & 2 & - & 2 & 13 & 11 \\
\hline 8 & Tauber Martin & 1 & 2 & 1 & 3 & - & - & 7 & 4 \\
\hline 9 & Novikov Serguei & - & 4 & 1 & 1 & - & 5 & 11 & 11 \\
\hline 10 & Jauhojaervi Sami & - & 3 & - & 1 & - & 6 & 10 & 4 \\
\hline
\end{tabular}

2 lentelè. Slidininkų, 2006 m. olimpinių žiemos žaidyniu 15 km lenktynèse klasikiniu stiliumi užèmusių 1-10 vietą, startų skaičius FIS kategorijos varžybose iki olimpinio šio nuotolio starto

\begin{tabular}{|c|l|c|c|c|c|c|c|c|}
\hline \multirow{2}{*}{$\begin{array}{c}\text { Užimta } \\
\text { vieta }\end{array}$} & $\begin{array}{c}\text { Slidininko pavarde, } \\
\text { vardas }\end{array}$ & $\begin{array}{c}10 \\
\mathrm{~km}\end{array}$ & $\begin{array}{c}15 \\
\mathrm{~km}\end{array}$ & $\begin{array}{c}30 \\
\mathrm{~km}\end{array}$ & $\begin{array}{c}\text { Kombinuotos } \\
\text { lenktynes } 15 \mathrm{~km} \\
\text { "K“+15 km „L“ }\end{array}$ & Sprintas & Ǐ̌ viso & $\begin{array}{c}\text { Dienų } \\
\text { skaičius nuo } \\
\text { paskutinio iki } \\
\text { olimpinio šio } \\
\text { nuotolio starto }\end{array}$ \\
\hline 1 & Di Centa Giorgio & 1 & 6 & 2 & 3 & SK & $12+$ SK & 6 \\
\hline 2 & Dementjev Eugenij & 1 & 6 & 1 & 3 & 3 & 14 & 6 \\
\hline 3 & Botvinov Mikhail & 2 & 5 & 1 & 1 & - & 9 & 13 \\
\hline 4 & Jonnier Emmanuel & 1 & 4 & 2 & 3 & - & 10 & 6 \\
\hline 5 & $\begin{array}{l}\text { Piller Cottrer } \\
\text { Pietro }\end{array}$ & 1 & 5 & 2 & 3 & - & 11 & 6 \\
\hline 6 & Soedergren Anders & 1 & 7 & 2 & 2 & - & 12 & 6 \\
\hline 7 & Kaukal Martin & 1 & 2 & 2 & 1 & $6+$ SK & $12+$ SK & 6 \\
\hline 8 & Magal Jiri & 2 & 7 & 2 & 2 & - & 13 & 6 \\
\hline 9 & Vittoz Vincent & 1 & 8 & 1 & 3 & - & 13 & 6 \\
\hline 10 & Fredriksson & 1 & 4 & 2 & 1 & - & 9 & 6 \\
\hline
\end{tabular}

Pastaba. SK - sprinto komandinès lenktynès olimpinèse žaidynèse.

3 lentelè. Slidininkų, 2006 m. olimpinių žiemos žaidynių $50 \mathrm{~km}$ lenktynèse laisvuoju stiliumi užèmusių $1-10$ vietą, startų skaičius FIS kategorijos varžybose iki olimpinio šio nuotolio starto

Pastaba. SK - sprinto komandinès lenktynès olimpinèse žaidynèse.

paskutinių varžybų iki olimpinio starto turèjo 21 dienos pertrauką.

Slidininkai, 15 km lenktynèse klasikiniu stiliumi užèmę $1-10$ vietą ( 2 lent.), iki šio olimpinio starto po $7-12$ kartų dalyvavo slidinejjimo lenktynèse. Slidininkams, $15 \mathrm{~km}$ lenktynèse užèmusiems 1, 5, 7, 11 vietą, šis startas buvo pirmas olimpinèse žaidynèse. Šie slidininkai po paskutinio starto oficialiose FIS kategorijos varžybose iki olimpinio starto turèjo 11 dienų pertrauką. Slidininkai, $15 \mathrm{~km}$ lenktynèse užèmę $2,3,6,8,10$ vietą, šiose olimpinèse žaidynèse jau dalyvavo $30 \mathrm{~km}$ kombinuotose lenktynèse, bet i pirmą dešimtuką nepateko. Šie slidininkai iki $15 \mathrm{~km}$ lenktynių turèjo tik keturių dienų pertrauką. 


\begin{tabular}{|c|c|c|c|c|c|c|c|c|c|c|c|c|c|c|}
\hline \multirow{12}{*}{$\begin{array}{l}4 \text { lentelè. Slidininkų, } \\
2006 \text { m. olimpinių } \\
\text { žiemos žaidynių indi- } \\
\text { vidualiose } 1,4 \text { km } \\
\text { sprinto lenktynèse } \\
\text { laisvuoju stiliumi } \\
\text { užèmusių } 1-10 \text { vie- } \\
\text { tą, startų skaičius iki } \\
\text { olimpinio šio nuotolio } \\
\text { starto }\end{array}$} & \multirow[b]{2}{*}{$\begin{array}{l}\text { Užimta } \\
\text { vieta }\end{array}$} & \multirow{2}{*}{\multicolumn{2}{|c|}{$\begin{array}{c}\text { Slidininko pavarde } \\
\text { vardas }\end{array}$}} & \multicolumn{9}{|c|}{ Startų skaičius iki olimpinio starto } & \multirow{2}{*}{\multicolumn{2}{|c|}{$\begin{array}{l}\text { Dienų skaičius } \\
\text { nuo paskutinio } \\
\text { iki olimpinio šio } \\
\text { nuotolio starto }\end{array}$}} \\
\hline & & & & $\begin{array}{r}10 \\
\mathrm{~km}\end{array}$ & $\begin{array}{r}15 \\
\mathrm{~km}\end{array}$ & $\begin{array}{r}30 \\
\mathrm{~km}\end{array}$ & \multicolumn{2}{|c|}{$\begin{array}{c}\text { Kombinuotos } \\
\text { lenktynès } \\
\text { „K“ } \mathrm{K}^{\text {” „L“ }}\end{array}$} & \multicolumn{2}{|c|}{$\begin{array}{l}\text { Individualus } \\
\text { sprintas }\end{array}$} & \multicolumn{2}{|c|}{$\begin{array}{c}\text { Komandinis } \\
\text { sprintas }\end{array}$} & & \\
\hline & 1 & \multicolumn{2}{|l|}{ Lind Bjoern } & - & - & - & \multicolumn{2}{|c|}{-} & \multicolumn{2}{|r|}{16} & \multicolumn{2}{|c|}{+} & \multicolumn{2}{|c|}{7} \\
\hline & 2 & \multicolumn{2}{|c|}{ Dargagon Roddy } & - & - & - & \multicolumn{2}{|c|}{-} & \multicolumn{2}{|r|}{29} & \multicolumn{2}{|c|}{-} & \multicolumn{2}{|c|}{11} \\
\hline & 3 & \multicolumn{2}{|c|}{$\begin{array}{l}\text { Fredriksson Tho- } \\
\text { bias }\end{array}$} & - & - & - & \multicolumn{2}{|c|}{ - } & \multicolumn{2}{|r|}{7} & \multicolumn{2}{|c|}{+} & \multicolumn{2}{|c|}{7} \\
\hline & 4 & \multicolumn{2}{|l|}{ Zorzi Cristian } & 1 & 3 & 1 & \multicolumn{2}{|c|}{-} & \multicolumn{2}{|r|}{10} & \multicolumn{2}{|c|}{-} & \multicolumn{2}{|c|}{2} \\
\hline & 5 & \multicolumn{2}{|c|}{$\begin{array}{l}\text { Schwienbacher } \\
\text { Freddy }\end{array}$} & - & 3 & 2 & \multicolumn{2}{|c|}{-} & \multicolumn{2}{|r|}{5} & \multicolumn{2}{|c|}{+} & 7 & \\
\hline & 6 & Frasnelli Loris & & - & 4 & - & 1 & & & 10 & & - & 11. & \\
\hline & 7 & Kjoelstad Joha & & - & - & - & - & & & 21 & & - & 17 & \\
\hline & 8 & Saarepuu Ant & & 1 & 1 & - & - & & & 13 & & + & 7 & \\
\hline & 9 & $\begin{array}{l}\text { Hattestad Ola } \\
\text { Vigen }\end{array}$ & & - & 1 & - & - & & & 16 & & - & 17 & \\
\hline & 10 & Hetland Tor $A$ & rne & - & 2 & - & - & & & 16 & & + & 13 & \\
\hline $\begin{array}{l}5 \text { lentelè. Slidinin- } \\
\text { kų, } 2006 \text { m. olimpi- }\end{array}$ & $\begin{array}{r}\text { Slidin } \\
\text { (pava }\end{array}$ & $\begin{array}{l}\text { inko inicialai } \\
\text { rde, vardas) }\end{array}$ & D. E. & E. & & P.-C. P. & Di-C. & & S. A. & V. V. & B. $\mathrm{M}$ & B. M. & O. M. & B. L. \\
\hline $\begin{array}{l}\text { nıų ziemos zaldynıų } \\
30 \mathrm{~km} \text { kombinuotose } \\
\left(15 \mathrm{~km}, \mathrm{~K}^{6}+15 \mathrm{~km}\right.\end{array}$ & $\begin{array}{l}\text { Užimta } \\
\text { olimpin }\end{array}$ & $\begin{array}{l}\text { vieta } \\
\text { ėse žaidynėse }\end{array}$ & 1 & 2 & & 3 & 4 & & 5 & 6 & 7 & 8 & 9 & 10 \\
\hline $\begin{array}{l}\text { „Č“") lenktynèse už- } \\
\text { èmusių } 1-10 \text { vietą, } \\
2005-2006 \text { m. Pasau- }\end{array}$ & $\begin{array}{l}\text { Užimta } \\
\text { taurès v } \\
\text { įskaitoj }\end{array}$ & $\begin{array}{l}\text { vieta Pasaulio } \\
\text { aržybų }\end{array}$ & 25 & 4 & & 7 & 8 & & 3 & 2 & 42 & 41 & 55 & 11 \\
\hline $\begin{array}{l}\text { lio taurės varžybų ga- } \\
\text { lutinės įskaitos vietos } \\
\text { pagal ilgųjų nuotolių } \\
\text { rezultatus }\end{array}$ & $\begin{array}{l}\text { Korelia } \\
\text { cientas } \\
\text { vietų } \\
\end{array}$ & $\begin{array}{l}\text { cijos koefi- } \\
\text { tarp užimtų }\end{array}$ & & & & & & & $=0,4^{\prime}$ & 1 & & & & \\
\hline $\begin{array}{l}6 \text { lentelè. Slidinin- } \\
\text { kų, } 2006 \text { m. olimpi- }\end{array}$ & $\begin{array}{r}\text { Slidini } \\
\text { (pava }\end{array}$ & $\begin{array}{l}\text { nko inicialai } \\
\text { rdé, vardas) }\end{array}$ & V. A. & B. L & & A. T. & R. V. & M. J. & & O. J. & S. A. & T. M. & N. S. & J. S. \\
\hline $\begin{array}{l}\text { nių žiemos žaidynių } \\
15 \mathrm{~km} \text { lenktynèse } \\
\text { klasikiniu stiliumi }\end{array}$ & $\begin{array}{l}\text { Užimta } \\
\text { olimpin }\end{array}$ & $\begin{array}{l}\text { vieta } \\
\text { ése žaidynèse }\end{array}$ & 1 & 2 & & 3 & 4 & 5 & & 6 & 7 & 8 & 9 & 10 \\
\hline $\begin{array}{l}\text { užèmusių } 1-10 \text { vie- } \\
\text { tą, } 2005-2006 \mathrm{~m} \text {. Pa- } \\
\text { saulio taurès varžybų }\end{array}$ & $\begin{array}{l}\text { Užimta } \\
\text { taurès v } \\
\text { itskaitoje }\end{array}$ & $\begin{array}{l}\text { vieta Pasaulio } \\
\text { aržybų }\end{array}$ & 18 & 11 & & 1 & 19 & 32 & & 50 & 30 & 24 & 27 & 34 \\
\hline $\begin{array}{l}\text { galutinès ịskaitos vie- } \\
\text { tos pagal ilgụjų nuo- } \\
\text { tolių rezultatus }\end{array}$ & $\begin{array}{l}\text { Korelias } \\
\text { cientas } \\
\text { vietų }\end{array}$ & $\begin{array}{l}\text { ijos koefi- } \\
\text { arp užimtų }\end{array}$ & & & & & & & 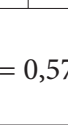 & 574 & & & & \\
\hline
\end{tabular}

Septyni pirmo dešimtuko slidininkai iki olimpinio $15 \mathrm{~km}$ nuotolio starto dalyvavo sprinto lenktynėse. $15 \mathrm{~km}$ lenktynèse ketvirtą vietą užèmęs Rusijos slidininkas V. Rotchev šiose olimpinėse žaidynėse laimejjo bronzos medali komandinèse sprinto lenktynèse ir iki antro olimpinio $15 \mathrm{~km}$ nuotolio starto turejjo tik dviejų dienu pertrauką. Visi $1-10$ vietą užèmę slidininkai iki $15 \mathrm{~km}$ nuotolio starto buvo po $1-3$ kartus dalyvavę kombinuotose $30 \mathrm{~km}$ lenktynèse.

$50 \mathrm{~km}$ lenktynèse laisvuoju stiliumi ir bendruoju startu i pirmą dešimtuką pateko šeši slidininkai, kurie $30 \mathrm{~km}$ kombinuotose lenktynèse taip pat buvo pirmame dešimtuke. Iki $50 \mathrm{~km}$ nuotolio starto pirmo dešimtuko slidininkai per olimpini sezoną buvo jau dalyvavę slidinèjimo lenktynèse (iskaitant startus olimpinèse žaidynèse, po 9-14 kartų) (3 lent.), bet jie daugiau kartu daly- vavo $15 \mathrm{~km}$ lenktynèse - nuo 2 iki 8 . İdomu tai, kad olimpiniu čempionu tapęs Italijos slidininkas G. Di Centa šiose olimpinès žaidynèse dalyvavo ir komandinèse sprinto lenktynėse, o Čekijos slidininkas M. Koukal, užèmęs aštuntą vietą $50 \mathrm{~km}$ lenktynèse, dalyvavo komandinèse ir individualiose sprinto lenktynèse (15 vieta).

Slidininkų, individualiose sprinto lenktynèse užèmusių $1-10$ vietą, varžybinè veikla šiuo olimpiniu sezonu iki olimpinių startų buvo gana ịvairi (4 lent.). Medalius laimejję slidininkai ir septintą vietą užèmęs slidininkas K. J. iki olimpinių žaidynių dalyvavo tik sprinto lenktynėse. Slidininkai, užèmę $4,5,6,8,9,10$ vietą, per sezoną iki olimpinių žaidynių dalyvavo sprinto lenktynèse ir po 1 -5 kartus ilgujų nuotolių lenktynèse.

Penki pirmo dešimtuko slidininkai olimpinèse žaidynèse dalyvavo ir komandinèse sprinto 


\begin{tabular}{|c|c|c|c|c|c|c|c|c|c|c|}
\hline $\begin{array}{l}\text { Slidininko inicialai } \\
\text { (pavardè, vardas) }\end{array}$ & Di.-C. G. & D. E. & B. M. & J. E. & P.-C. P. & S. A. & K. M. & M. J. & V. V. & F. M. \\
\hline $\begin{array}{l}\text { Užimta vieta } \\
\text { olimpinėse žaidynèse }\end{array}$ & 1 & 2 & 3 & 4 & 5 & 6 & 7 & 8 & 9 & 10 \\
\hline $\begin{array}{l}\text { Užimta vieta Pasaulio } \\
\text { taurès varžybų } \\
\text { ìskaitoje }\end{array}$ & 8 & 25 & 42 & 12 & 7 & 3 & 69 & 26 & 2 & 6 \\
\hline $\begin{array}{l}\text { Koreliacijos koefi- } \\
\text { cientas tarp užimtų } \\
\text { vietų }\end{array}$ & \multicolumn{10}{|c|}{$r=-0,079$} \\
\hline
\end{tabular}

\begin{tabular}{|l|c|c|c|c|c|c|c|c|c|c|}
\hline $\begin{array}{l}\text { Slidininko inicialai } \\
\text { (pavardé, vardas) }\end{array}$ & L. B. & D. R. & F. T. & Z. C. & S. F. & F. L. & K. J. & S. A. & H. O. V. & H. T.-A. \\
\hline $\begin{array}{l}\text { Užimta vieta } \\
\text { olimpinėse žaidynèse }\end{array}$ & 1 & 2 & 3 & 4 & 5 & 6 & 7 & 8 & 9 & 10 \\
\hline $\begin{array}{l}\text { Užimta vieta Pasaulio } \\
\text { taurès varžybu } \\
\text { iskaitoje }\end{array}$ & 1 & 23 & 2 & 12 & 38 & 18 & 5 & 20 & 16 & 3 \\
\hline $\begin{array}{l}\text { Koreliacijos koefi- } \\
\text { cientas tarp užimtu } \\
\text { vietuc }\end{array}$ & \multicolumn{10}{c|}{$r=0,028$} \\
\hline
\end{tabular}

7 lentelè. Slidininkų, 2006 m. olimpinių žiemos žaidynių $50 \mathrm{~km}$ lenktynèse laisvuoju stiliumi užèmusių 1-10 vietą, $2005-2006 \mathrm{~m}$. Pasaulio taurès varžybụ galutinès įsaitos vietos pagal ilgųjų nuotolių rezultatus

8 lentelè. Slidininku, 2006 m. olimpinių žiemos žaidynių sprinto $1,4 \mathrm{~km}$ lenktynèse laisvuoju stiliumi užèmusių $1-10$ vieta, 2005 2006 m. Pasaulio taurès varžybų galutinės įskaitos vietos pagal sprinto rezultatus lenktynėse. Slidininkai, dalyvaujantys komandinèse sprinto lenktynėse, iki starto individualiose sprinto lenktynèse turejo septynių dienu pertrauką. Slidininkai, sprinto lenktynèse patekę i pirmą dešimtuką, bet nedalyvavę komandinèse sprinto lenktynėse, turejjo $11-17$ dienų pertrauką iki olimpinio starto po paskutiniu oficialiu FIS kategorijos slidinejjimo lenktynių.

Norvegijos slidininkas T.-A. Hetland, individualiose sprinto lenktynèse užèmęs dešimtą vietą, o komandinèse laiméjęs sidabro medali, dalyvavo $50 \mathrm{~km}$ lenktynèse laisvuoju stiliumi ir užèmè 33ią vietą, atsilikęs nuo šių lenktynių laimètojo tik $1 \min 24,4 \mathrm{~s}$.

Slidininkų sportinių rezultatų, pasiektų olimpinèse žaidynėse, sąsają su jų rezultatais Pasaulio slidinejjimo taurès varžybose (Cross-country ${ }^{4}$ ) rodo duomenys, pateikti 5, 6, 7, 8 lentelëje. Olimpinèse žaidynèse individualiose slidinejjimo lenktynèse (keturių nuotolių) i pirmus dešimtukus pateko 33 slidininkai. Iš jų septyni slidininkai Pasaulio taurès daugiaetapių varžybu galutinejje ịskaitoje pagal ilgųjų nuotolių lenktynių rezultatus $(15-50 \mathrm{~km})$ buvo pirmame dešimtuke $(5,6,7$ lent.), o trys slidininkai pateko į Pasaulio taurès sprinto varžybu pajègiausiujų dešimtuką (8 lent.). Individualiose slidinejjimo lenktynèse olimpinius medalius laimèjo 11 slidininku (Cross-country $\left.{ }^{3}\right)$. Keturi olimpinių medaliu laimètojai Pasaulio slidinèjimo taurès varžybu galutinèje įskaitoje buvo pajègiausiujų dešimtuke pagal ilgujų nuotolių rezultatus. Individualių sprinto lenktynių aukso ir bronzos olimpinių medalių laimètojai Pasaulio taurès sprinto varžybu galutinejje įskaitoje užèmé pirmą ir antrą vietas (8 lent.).

\section{REZULTATŲ APTARIMAS}

Pasaulio pajėgiausieji slidininkai kiekvieną sezoną dalyvauja daugiaetapèse Pasaulio slidinèjimo taurès varžybose. Pasaulio taurès etapų varžybos prasideda spalio pabaigoje ir baigiasi kovo antroje pusejje. Olimpiniu 2005-2006 m. sezonu per Pasaulio taurès varžybas buvo 15 individualiu slidinèjimo ilgujų nuotolių (15-50 km ir $90 \mathrm{~km}$ ) lenktynių, dvejos $4 \times 10 \mathrm{~km}$ estafečių lenktynès, devynerios individualios ir trejos komandinès sprinto varžybos (Cross-country ${ }^{2}$ ).

Pasaulio slidinèjimo taurès varžybų įskaitoje nustatomas trijų tipų slidininkų užimtos vietos pagal (Cross-country $\left.{ }^{4}\right)$ :

- bendrą taškų sumą už ilgujų nuotolių ir sprinto lenktynių rezultatus;

- taškus, gautus tik už ilgujų nuotolių rezultatus;

- taškus, gautis tik už sprinto rezultatus.

Elito slidininkus dalyvauti Pasaulio slidinèjimo taurès varžybose ir siekti aukštų vietų galutineje iskaitoje skatina tai, kad $1-6$ vietos laimètojai kiekvieno etapo lenktynèse ir galutinejje Pasaulio taurès varžybu iskaitoje apdovanojami piniginiais prizais, pagal rezultatus Pasaulio taurès varžybų bendrojoje i̇skaitoje slidininkai gauna ir Tarptautinès slidinejjimo federacijos materialinę paramą už dalyvavimą Pasaulio taurès varžybose. Slidininkams, siekiantiems puikių rezultatų bendroje Pasaulio taurès varžybų įskaitoje, reikia ne tik užimti aukštas vietas taurès etapinèse lenktynèse, bet dažnai dalyvauti jose ir pelnyti iskaitinius taškus. Olimpiniais metais ir pasaulio slidinėjimo 
čempionatų metais elito slidininkams labai svarbu tinkamai suplanuoti startus siekiant geriausios sportinès formos per pagrindines varžybas.

Olimpiniu čempionu $15 \mathrm{~km}$ lenktynèse klasikiniu stiliumi tapęs Estijos slidininkas A. Veerpalu Pasaulio taurès varžybų galutinėje įskaitoje pagal ilgujjų nuotolių rezultatus užèmė tik 11 vietą ir per olimpini sezoną iki olimpinio starto Pasaulio taurès lenktynèse nebuvo laimèjęs prizinès vietos (geriausias rezultatas - dvi penktos vietos).

Olimpinis $30 \mathrm{~km}$ kombinuotų lenktynių čempionas ir $50 \mathrm{~km}$ lenktynių laisvuoju stiliumi sidabro medalio laimètojas Rusijos slidininkas E. Dementjev Pasaulio taurès varžybu galutinèje ískaitoje pagal ilguju nuotolių rezultatus užèmè tik 25 -ą vietą. Absoliutus Pasaulio slidinejjimo taurès varžybu laimètojas T. Angerer olimpinèse žaidynėse laimèjo tik bronzos medali $15 \mathrm{~km}$ lenktynèse klasikiniu stiliumi, o $30 \mathrm{~km}$ kombinuotose lenktynèse ir $50 \mathrm{~km}$ lenktynèse laisvuoju stiliumi net nepateko i pirmą dešimtuką. Prancūzijos slidininkas V. Vittoz per olimpini sezoną iki olimpiniu startu buvo laimèjęs prizines vietas penkiose Pasaulio slidinejjimo taurès lenktynèse, o galutinejje $\mathrm{Pa}$ saulio taurès varžybu įskaitoje užèmè antrą vietą pagal ilgujų nuotolių rezultatus ir užèmé penktą vietą absoliučioje iskaitoje, tačiau per olimpines žaidynes medalio nelaimèjo, nors dalyvavo 15,30 , $50 \mathrm{~km}$ lenktynèse ir pateko i̇ pirmą dešimtuką 30 ir $50 \mathrm{~km}$ lenktynèse, o $15 \mathrm{~km}$ lenktynèse užèmè 15 -ą vietą.

Nustateme, kad tarp slidininkų (patekusių $i$ pirmus dešimtukus) užimtų vietų individualiose lenktynèse per olimpines žaidynes ir tų pačių slidininkų užimtų vietų Pasaulio taurès varžybų galutinèje įskaitoje koreliacinis ryšys silpnas arba jo nèra $(5,6,7,8$ lent.).

Šiuolaikinei didžiojo sporto raidai būdingos profesionalizacijos ir komercializacijos tendencijos, kurios pasireiškia tarptautinių varžybų, Pasaulio taurès varžybų kalendoriaus prasiplètimu (Suslovas, 1999, 2002; Шустин, 2003). Siekimas didžiają sezono dali rodyti puikius rezultatus skatina per daug forsuoti ir specializuoti krūvius, keisti bendrojo ir specialiojo rengimo priemoniu tarpusavio santykị, o tada dažnai pastebimas rezultatų nestabilumas, padidèjusi nesėkmių tikimybė per svarbiausias varžybas (Suslovas, 1999). Dèl didelio startų skaičiaus ir treniravimuisi skirto laiko sumažèjimo neretai prastėja sportininkų parengtumas ir varžybinès veiklos kokybė (Suslovas, 1999; Рубин, 1999; Шустин, 2003).
Varžybinè veikla rengimosi svarbiausiems startams etapu turi parengti sportininko organizmą specifiniam didelio galingumo darbui, išugdyti gebejjimą efektyviai realizuoti savo motorini potencialą per varžybas (Верхошанский, 1998).

Didelị slidininkų darbingumą per slidinėjimo lenktynes lemia aerobinès ir anaerobinès laktatinès energijos gamybos sistemų aukštas lygis, didelis deguonies suvartojimas ir didelis darbo galingumas ties anaerobinio slenksčio riba (Раменская, 2000; Головачев и др., 2003).

2005-2006 m. sezono Pasaulio slidinejjimo taurès varžybų absoliučioje įskaitoje (pagal iskaitinius taškus už ilgujų nuotolių ir sprinto rezultatus) i pirmą dešimtuką pateko šeši slidininkai, turintys įskaitinių taškų už rezultatus ilguju nuotoliu $(15-50 \mathrm{~km})$ ir sprinto lenktynèse $\left(\right.$ Cross-country $\left.{ }^{4}\right)$. I triju pajègiausių Pasaulio taurès varžybų slidininkų dešimtuką absoliučioje iskaitoje pateko penki ilgujų nuotoliu slidininkai, trys sprinteriai ir du universalūs slidininkai. Pirmo dešimtuko slidininkų gautų taškų suma siekè: $62,95 \%$ už ilgujų nuotolių rezultatus ir $37,05 \%$ - už sprinto rezultatus. Elito slidininkus pagal jų varžybinę veiklą galima skirstyti i dvi grupes: vidutinių, ilguju nuotolių slidininkus ir slidininkus sprinterius.

Slidinejjimo lenktynèse bendruoju startu slidininkų vietų sklaidai daug įtakos turi jų slydimo greitis finišuojant, o dažniausiai — slidinèjimo stadione. Ilgujų nuotolių slidininkams reikia ne tik ištvermès, bet ir gebejimo pasiekti didelị maksimaluji slydimo greití. Dèl to ilgujų nuotolių slidininkai dalyvauja ir sprinto lenktynėse.

Kombinuotos lenktynès skatina slidininku universalumą, nes šiose lenktynėse gerų rezultatu gali pasiekti tik gebantys puikiai šliuožti klasikiniais ir čiuožiamaisiais slydimo būdais. Olimpinèse žaidynèse šeši pirmo dešimtuko $30 \mathrm{~km}$ kombinuotų lenktynių slidininkai pateko ir i pirmą pajègiausiuju $50 \mathrm{~km}$ lenktyniu laisvuoju stiliumi dešimtuką. Iš slidininkų, 15 km lenktynèse klasikiniu stiliumi užèmusių $1-10$ vietą, tik vienas pateko i pirmą $30 \mathrm{~km}$ kombinuotu lenktynių dešimtuką.

Pagal elito slidininkų varžybinès veiklos pobūdị ir rezultatyvumą santykiškai galima išskirti universalius, klasikinio ir čiuožiamojo stiliaus slidininkus. Elito slidininkai per pagrindines varžybas (olimpines žaidynes) dalyvauja 2-4 nuotolių lenktynėse (tarp jų ir estafečių lenktynèse). 


\section{IŠVADOS}

1. Elito ilgujų nuotolių slidininkai iki pagrindinių sezono varžybų dalyvauja po 8-12 kartų individualiose įvairių nuotolių lenktynėse.

2. Elito slidininkus pagal jų varžybinès veiklos specifiką galima skirstyti i dvi grupes - vidutinių bei ilgujų nuotolių slidininkus ir slidininkus sprinterius.
3. Pagal varžybinès veiklos veiksmingumą šliuožiant skirtingais slydimo stiliais santykiškai skiriami universalūs, klasikinio ir čiuožiamojo stiliaus slidininkai.

4. Ilgujų nuotolių slidininkai rengimosi svarbiausioms varžyboms etapu dalyvauja ir sprinto lenktynèse.

\section{LITERATŪRA}

Cross-country ${ }^{1}$. Biography. Athlete information. Prieiga per interneta: http://www.fis-ski.com

Cross-country ${ }^{2}$. FIS World Cup Calendar 2005-2006. Prieiga per internetą: http://www.fis-ski.com

Cross-country ${ }^{3}$. Results. Olympic Winter Games. Prieiga per interneta: http://www.fis-ski.com

Cross-country ${ }^{4}$. World Cup Standings. Prieiga per internetą: http://www.fis-ski.com

Čepulènas, A. (1998). Slidininkų lenktynininkų varžybinès veiklos ir sportinių rezultatų kitimo tendencijos olimpinèse žiemos žaidynèse. Sporto mokslas, 4 (13), 50-54.

Fominas, S. (2001). Žiemos sporto šakų raida pasaulyje ir nacionalinių komandų pajègumo santykis prieš 2002 metǔ žiemos olimpines žaidynes Solt Leik Sityje. Sporto mokslas, 4 (26), 52-57.

Kardelis, K. (2002). Moksliniu tyrimu metodologija ir metodai. Kaunas: Judex. P. 231-237.

Karoblis, P. (2005). Sportinio rengimo teorija ir didaktika. Vilnius: Inforastras.

Kindinger, W., Spitz, L., Nittel, R. (2004). Top Team Turin - die Kanzeption der Vorbereitung des deutschen Wintersports auf die XX. Olympischen Winterspiele 2006 Turin. Leistungssport, 3 (34), 28-30.

Pfützner, A., Reiss, M., Rost, K. (2002). Internationale und nationale Entwicklungstendenzen auf Grundlage der Ergebnisse der Olympischen Winterspiele in Solt Lake City mit Folgerungen für den Olympiazyklus 2002 / 2006. Leistungssport, 3 (32), 20-26.

Stöggl, T., Lindinger, S., Müller, E. (2006). Loading analysis of a classical cross-country skiing sprint simulation. International Congress on Science and Nordic Skiing, June 18-20, 2006: Congress Proceedings (p. 31). Vuokatti, Finland.

Suslovas, F. (1999). Individualių sporto šakų varžybu sistema šiuolaikiniame sporto raidos etape. Treneris, 2 , $22-31$.
Suslovas, F. (2002). Patyrusių sportininkų rengimo olimpinèms žaidynèms strategija. Sporto mokslas, 1 (27), 5-9.

Watts, P. B., Ryan, J. M., Jensen, R. L. (2006). Changes in technique-specific $\mathrm{VO}_{2} \max$ and competitive performance over a season in collegiate cross-country skiers. International Congress on Science and Nordic Skiing, June 18-20, 2006: Congress Proceedings (p. 66). Vuokatti, Finland.

Верхошанский, Ю.В. (1998). Горизонты научной теории и методологии спортивной тренировки. Теория и практика физической культуры, 7, 41-54.

Головачев, А. И., Бутулов, Э. Л., Кондратов, Н. Н., Потоцкий, В. Л., Богданов, П. Б. (2003). Влияние возрастных и квалификационных особенностей на уровень физической подгтовленности спортсменов (на примере лыжных гонок). Теория и практика физической культуры, 10, 32-34.

Мелленберг, Г. В., Сайдхужин, Г. Р. (1994). Концепция специализированного тренировочного моделирования соревновательной деятельности. Теория и практика физической культуры, 9, 14-20.

Плохой, В. Н. (1995). Перспективы специализации в лыжных гонках к различным по длине дистанциям. Теория и практика физической культуры, 1, 41-42.

Раменская, Т. И. (2000). Биоэнергетическое моделирование соревновательной деятельности сильнейших лыжников-гонщиков на XVIII зимних олимпийских играх (Нагано). Теория и практика физической кульmуры, 2, 6-12.

Рубин, В. С. (1999). Стратегия олимпийской подготовки. Теория и практика физической культуры, 7, $28-31$.

Шустин, Б. Н. (2003). Концептуальные основы подготовки сборной команды России к олимпийским играм. Теория и практика физической культуры, 10, 27-31. 


\title{
CHARACTERISTICS OF ELITE SKIERS' COMPETITION ACTIVITY
}

\author{
Algirdas Čepulėnas \\ Lithuanian Academy of Physical Education, Kaunas, Lithuania
}

\begin{abstract}
Appropriately and individually planned competition ensures consistent improvement in athlete's physical efficiency, good athletic condition before the main competition.

Now the program of skiing competition is diverse: skiing competition in classical style ways, competition with separate start, competition with massive start, combined competition "Pursult" (half of the distance is skied in classical ways and another half of the distance is skied using skiing steps), individual and team sprint competition. Each way of skiing has specific requirements for adaptation of skier to competition activity.

The problem of specialization of the world elite skiers in different skiing styles and particular competition programs has not been analyzed much. Scientific literature lacks information about the amount of elite skiers' competition activity and its structure during the preparation for the main start of the season.

The aim of the research - to analyse the amount and the structural components of the world elite skiers' competition activity during the Olympic year cycle.

The subject of the analysis - peculiarities of the competition activity of skiers racers, who took the 1st-10th places in the individual competition of Turin Olympic Winter Games.

The analysis of the competition activity during 2005/2006 season of skiers, who took the 1 st-10th places in the individual competition in Turin Olympic Winter Games, was carried out.

Skiers, who took the 1st-10th places in $30 \mathrm{~km}$ combined competition (Pursulte) 8-12 times took part in the World Skiing Cup and FIS category competitions before the Olympic Games. Skiers took part in 15 $\mathrm{km}$ competitions $3-7$ times, $1-2$ times in $30 \mathrm{~km}$ competition and $1-2$ times in Pursulte competition. Six skiers, who were taken to the first decade in $30 \mathrm{~km}$ competition, were in the first decade of the strongest skiers in $50 \mathrm{~km}$ competition in free style skiing.

Skiers, who took the $1 \mathrm{st}-10$ th places in $15 \mathrm{~km}$ competition in classic style, took part in different skiing distance competitions 7-13 times before the Olympic Games. Those skiers also took part in skiing sprint competition $2-6$ times. Skiers, who took the 1 st-10th places in individual skiing sprint competition 5-29 times took part in skiing sprint competitions before the Olympic starts. Skiers of this group (with the exception of T. A. Hetland (Norway)) did not take part in other individual games of the Olympic skiing program.

Elite skiers can be divided into two groups according to the specifics of their competition activity: skiers of medium-length distances and skiers sprinters. There we can distinguish three groups of skiers according to the strategy of preparation of elite skiers for the main starts and competition activity scoring: skiers of classic style, universal skiers, and skiers of sliding style.
\end{abstract} sprint.

Keywords: Winter Olympic Games, elite skiers' competition activity, classical style, free style, skiing

Gauta 2006 m. rugsèjo $1 \mathrm{~d}$.

Received on September 1, 2006

Priimta 2006 m. gruodžio $6 \mathrm{~d}$.

Accepted on December 6, 2006
Algirdas Čepulènas

Lietuvos kūno kultūros akademija

(Lithuanian Academy of Physical Education)

Sporto g. 6, LT-44221 Kaunas

Lietuva (Lithuania)

Tel +370 37302645

E-mail a.cepulenas@lkka.1t 